\title{
The Language of Science and Readability: Correlations between Linguistic Features in TIMSS Science Items and the Performance of Different Groups of Swedish 8th Grade Students
}

\author{
Tomas Persson $\star$ \\ Department of Education, Uppsala University, Uppsala, Sweden
}

\begin{abstract}
This exploratory study examines how linguistic features of the Swedish TIMSS 2011 grade 8 science items correlate with results from different groups of students. Language use in different science subjects is analysed using four characteristic meaning dimensions of scientific language: Packing, Precision, Presentation of information, and Personification within the text, along with established measures of readability and information load.

For each subject, one or more of the meaning dimensions show statistically significant correlations with students' performances with small to medium effect sizes. The results show that higher packing is positively correlated with students' results in earth science, negatively correlated in physics, and has no significant correlations in biology or chemistry. Placing items in everyday contexts reduces the likelihood of the items being answered correctly, and skilled readers are aided by higher precision in items, while less skilled readers seem unaffected. Many meaning dimensions that influence high performers' results do not influence those of low performers, and vice versa. The use of meaning dimensions is shown to be an enriching complementary method for analysing language use in science, as it connects the language use in items to student performance, while established measures do not.
\end{abstract}

Keywords: science education; scientific language; readability formulas; assessment; student achievement

Received: October 2015; Accepted: March 2016; Published: May 2016

\section{Introduction}

Drawing conclusions about students' scientific understanding from answers to test questions is not an easy task. Most teachers know that there are many different ways - other than those intended - for students to interpret questions. Research on

*Correspondence to: Tomas Persson, Department of Education, Uppsala University, Box 2136, SE-750 02 Uppsala, Sweden. Email: tomas.persson@edu.uu.se 
tests has shown that incorrect responses do not necessarily indicate a lack of knowledge about a concept (e.g. Harlow \& Jones, 2004; Oakland \& Lane, 2004; Rodrigues, Haladyna, \& Downing, 2002; Schoultz, 2000). It can be caused by poorly constructed questions, students' lack of vocabulary, poor reading skills, or misinterpretations of (elements within) questions. Consequently, that which is measured is influenced by the reading demands the questions have, rendering it necessary to investigate the relationship between students' results and the reading demands of the questions.

This study analyses approximately 200 science items and 5,500 students' answers from the 2011 Swedish version of the international study TIMSS-the Trends in International Mathematics and Science Study by the International Association for the Evaluation of Educational Achievement (IEA) (Mullis, Martin, Ruddock, O'Sullivan, \& Preuschoff, 2009). The understanding of the interaction between language use and student performance can be improved by examining how characteristic meaning dimensions of science, that is, the Packing, Precision, Personification, and Presentation of information (see Persson, af Geijerstam \& Liberg, in press), in items from different scientific subject areas, correlate with the performance of different student groups. Items are also analysed using established measures of readability and information load. The results from this study can therefore help teachers adapt their teaching in specific subjects to better suit various student needs when learning science. This study can also help broaden the theoretical base of how readability formulas can be designed by introducing a quantitative method based on a social semiotic perspective to analyse the language use in short science items. As English is the target language for most readability studies, with few large-scale studies existing in Swedish (Heimann Mühlenbock, 2013), testing a method that is not confined to one language can contribute not only to Swedish readability research but also to readability research in general.

\section{Aims of the study}

By analysing science items with meaning dimensions in addition to more established readability measures, this study intends to highlight some of the ways that language use in different kinds of items correlates with the performance of different groups of students taking the test. Using students' results and items from the Swedish version of TIMSS 2011, this study will answer the following research questions:

How do meaning dimensions in the language used in items in different science subject areas correlate with how different groups of 8th grade students succeed in answering these items?

What differences can be found when comparing results from this analysis using meaning dimensions with corresponding results from established measures of readability and information load? 


\section{Previous research}

\subsection{Relationships between the reader and text}

Using three data sets (2000, 2003, and 2006) from the Program for International Student Assessment (PISA) (OECD, n.d.), an international study, Cromley (2009) found large correlations (e.g. 0.859, 0.876, and 0.842 for Sweden) between students' performances in science and their reading scores. Three explanations were hypothesized: reading comprehension causes scientific proficiency; scientific proficiency causes reading comprehension; or that a third factor causes both reading comprehension and scientific proficiency.

Although I am not able to test the three primary hypotheses with these data, I lean toward the third explanation: that background knowledge, reading comprehension strategies, general vocabulary, inference, and other products of extensive reading experience also drive higher science proficiency. (Cromley, 2009, p. 115)

Cromley concludes that one way to improve results on science tests might be to improve students' comprehension of written science texts. Advocating the concept of disciplinary literacy, Shanahan and Shanahan (2012) argue that it is the differences between the disciplines that create texts with different requirements for readers. To be a successful reader, students must understand how to use different approaches to reading and writing in different disciplines, as opposed to acquiring some sort of general reading skill. Teaching that focuses on general literacy skills and abilities that can be applied across content areas is suitable for younger children, but as students get older, reading and writing instruction should become increasingly disciplinary, addressing the specific reading demands of different disciplines or subjects (Shanahan \& Shanahan, 2008). As many linguistic features are specific to particular discourses, it is more beneficial for students to be given an understanding of specific features in the discourses they will encounter than to search for overarching, universally applicable teaching items (Hyland \& Tse, 2007).

Schoultz (2000) has shown that interpreting science items is a major problem for students. This may be due to single technical terms that students do not understand, or highly abstract examples that are difficult to connect to the response options. Some students may have the necessary skills and strategies to solve a problem, but if they do not understand the question as such, they will probably not be able to answer it correctly. Harlow and Jones (2004) found that ambiguous language use in TIMSS created opportunities for different interpretations, resulting in answers that did not always reflect students' actual knowledge. Items must therefore minimize ambiguity, be at a suitable language level, and be comprehensible to all participants (Harlow \& Jones, 2004). Furthermore, students may not understand that certain questions are scientific questions when they are placed in an everyday context (Schoultz, 2000). Studying students' group discussions when solving PISA items, Serder and Jakobsson (2014/2015) found that students distanced themselves from scientific language use in everyday situations, often expressed as fictitious students in the test. 
Regarding the performance of students in Sweden on the international tests, a decline in the past 10-15 years has been identified in most areas tested. Moreover, except for 4 th grade reading, the results in science and reading for Swedish students have declined more for low performers than for high performers, but in recent years, the number of students performing at higher levels in reading has also decreased. In science, however, such decreases do not reach significant levels (Skolverket, 2012a, 2012b, 2012c, 2013). An analysis of TIMSS 2007 chemistry item responses showed that, compared with low/average performers, high performers wrote longer answers with a more frequent use of passives, technical terms, and colloquial words with specific scientific meanings (Kokkinakis \& Frändberg, 2013). Comparing changes in attitudes towards science between 1995 and 2007, it was found that in 2007, high performers in Sweden - especially boys - were more negative, with both high- and low-performing boys finding science more boring (Adolfsson, 2011). Adolfsson also found that Swedish boys are more positive towards physics and chemistry, and girls are more positive towards biology. Furthermore, high performers have positive attitudes towards studies and their own abilities, and devote more time to reading and less to TV, Internet, and computer games (Skolverket, 2012b, 2012c). On the contrary, in 2007 low performers thought they performed better in all subjects compared with how low performers thought they did in 1995 (Adolfsson, 2011).

The international studies, PISA and Progress in International Reading Literacy Study (PIRLS), show that girls are better readers than boys in almost all participating countries (Skolverket, 2012a, 2013). In Sweden, there were also large differences between boys and girls regarding science results in TIMSS 1995 and 2003, but not in 2007. The only detectable difference in 2011 was in biology, in favour of girls (Skolverket, 2012b). In PISA 2012, Swedish girls outperformed boys in science for the first time since the start of PISA in 2000 (Skolverket, 2013).

The text format looks different in different contexts, which may also impact performance. In TIMSS and many other tests, the main item formats are multiple choice (select correct answer) and constructed response (write own answer), which can (or does) measure different skills or processes (Hogan \& Murphy, 2007). Using the TIMSS 1995 items, Olsen, Turmo, and Lie (2001) showed that even minor changes to wording and/or changing an item's format can have a large impact on student response patterns. Sweden was among the top three countries regarding strong connections between gender and item format in the TIMSS 1995 science items (Hastedt \& Sibberns, 2005). Analysing TIMSS 2003, Eriksson (2005) found that boys performed as well as girls in multiple choice items in biology, and girls performed as well as boys in constructed response items in physics, with Sweden again among the top three countries when ranking the importance of item format and gender. Several surveys show that boys seem to benefit from multiple choice items and girls from constructed response items, but other aspects may also contribute to these results (e.g. Eriksson, 2005; Hastedt \& Sibberns, 2005). 


\subsection{The text, readability and meaning dimensions}

Different ways of capturing the complexity of a text have been developed, and starting in the 1920 s, text complexity began to be calculated using formulas, resulting in over 200 formulas by the 1980s (DuBay, 2007). Most readability formulas use at least two quantitatively measured qualities of language: vocabulary and syntax. Vocabulary is often measured by counting syllables/letters or using word frequencies; syntax is often determined by sentence length (Oakland \& Lane, 2004). Most formulas are regression formulas, where parameters are given different weights (Heimann Mühlenbock, 2013). The Flesch Reading Ease and Flesch-Kincaid Grade Level formulas (Kincaid, Fishburne, Rogers, \& Chissom, 1975) exemplify weighting, as both use the number of words per sentence and syllables per word, but they are multiplied by different weights. The formula's resulting number corresponds with either a grade in school (e.g. Flesch-Kincaid Grade Level) or has to be interpreted with a table (e.g. Flesch Reading Ease) (DuBay, 2007). The Swedish language has long been limited to the table-interpreted formula LIX, LäsbarhetsIndeX [readability index] (Heimann Mühlenbock, 2013), using the percentage of long words ( $>6$ characters) per word added to the average number of words per sentence (Björnsson, 1968). The three readability formulas above are all included as an optional choice when conducting grammar and spelling checks in Microsoft Word 2010.

Computer-based text analysis can be considered more objective and reliable than manual analysis (Graesser, McNamara, \& Kulikowich, 2011), but traditional readability formulas have disadvantages whether they are calculated by computers or not, as they measure features on a general surface level (e.g. word and sentence length) and not on a language-specific structural level (Graesser et al., 2011; Oakland \& Lane, 2004). More sophisticated computer linguistic analysis tools are available, but they still have problems with texts for which the programme has not been developed, allowing for systematic errors. Another problem is that computerbased analysis cannot measure coherence: if the sentences of a coherent text are shuffled to become incoherent, the two texts still earn the same score (Torvatn, 2004). Therefore, manual checking cannot be discarded as obsolete yet. Other problems occur when text samples are too short, causing values to fluctuate in unpredictable ways. Many readability formulas use sentence length, since it is one of the best predictors of a text's readability (Dubay, 2007), but sentence length alone might not be enough to measure a text's readability (Bailin \& Grafstein, 2001).

Authors and publishers became aware of readability issues in the late 1970s, when the majority of school textbooks analysed with readability formulas were found to be at reading levels that were too high (Wellington \& Osborne, 2001). However, writing for easy-to-read formulas instead of readers has its drawbacks: omitting logical connectives and reducing sentence length can produce staccato sentences with stilted, non-fluent, or incoherent prose (Wellington \& Osborne, 2001). Laursen (2006) shows that the use of short sentences and passages in a Danish school science textbook makes the text look easy, but making connections between passages and sentences is very hard. There is a trade-off to consider here: text difficulty may 
rise in shorter texts, as background information becomes limited and idea density increases.

Another type of language measure concerning density is Lexical Density, calculated as the number of content words: nouns, verbs, adjectives, some adverbs, either per non-embedded clause (Halliday \& Matthiessen, 2004) or per total words (Eggins, 1994). Two well-established Swedish measures are Nominal Ratio, the number of nouns, prepositions, and participles divided by the number of verbs, pronouns, and adverbs, and Simple Nominal Ratio, nouns divided by verbs (Einarsson, 1978). These two measures are based on the fact that a dense language has many nouns, while a less dense language (e.g. spoken language) has many verbs (Graesser et al., 2011). Nouns and verbs can be considered complementary in this regard: high proportions of verbs in texts indicate a low proportion of nouns and vice versa (Heimann Mühlenbock, 2013). Another measure indicating text complexity is the Nouns per Pronouns ratio (Heimann Mühlenbock, 2013).

Many of these measures are thus developed empirically, rather than firmly placed within a theoretical framework. Within the context of this study, typical features of language used in written science texts have instead been investigated from a social semiotic perspective, as developed in systemic functional linguistics (SFL) (e.g. Halliday \& Matthiessen, 2004). From this perspective, linguistic features are perceived as serving to create three main types of meaning: ideational meaning, through which the content of a text is expressed, interpersonal meaning, which expresses personal relationships in the text and with the reader/listener, and textual meaning, in order to express how the text is structured in terms of how information is organised and presented. Linguistic features that are characteristic of a scientific language are therefore thought to fulfil these functions to create meaning. Linguistic features found in earlier research (see e.g. Graesser et al., 2011; Halliday \& Martin, 1993; Lemke, 1990; Schleppegrell, 2004; Veel, 1997) to be characteristic of language use in written science texts will therefore be regarded from an SFL perspective. From this perspective, it could be concluded that linguistic features typical of written science texts serve to pack the information and make it more precise (i.e. dimensions of ideational meaning), to downgrade personal relationships (i.e. dimensions of interpersonal meaning), and to present the information in more complex ways (i.e. dimensions of textual meaning). The Packing, Precision, Personification, and Presentation of information are thus considered central meaning dimensions of scientific language. In accordance with earlier research, different linguistic features are used in the analysis to indicate these dimensions (see Table 1).

Packing is expressed through long words and nouns (including nominalizations) indicating the information density. Linguistic features that operate as different types of modifiers express the level of Precision in the language. Personification reflects personal relationships within the text and between the text and the reader. Presentation reflects the complexity of how the information is presented to the reader.

To demonstrate how meaning dimensions are calculated, the calculation of Packing in chemistry item S032679 from TIMSS 2011 is shown below. The original English phrasing is: Write down one thing you might observe that shows that energy has 
Table 1. Linguistic features building up meaning dimensions

\begin{tabular}{ll}
\hline Meaning dimension & Linguistic feature (per words in the item) \\
\hline Packing & Nouns + long words \\
Precision & Adjectives + adverbs + counting words + descriptive names ${ }^{\mathrm{a}}+$ participles \\
Personification & $(1 \mathrm{st}, 2 \mathrm{nd}, 3 \mathrm{rd}$ person $)$ pronouns + proper names \\
Presentation & Passives + subordinate clauses \\
\hline
\end{tabular}

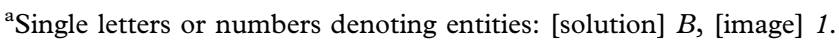

been released during a chemical reaction (Foy, Arora, \& Stanco, 2013). The Swedish version is: Beskriv en sak som du kan observera som visar att energi har frigjorts vid en kemisk reaktion (Skolverket, 2014). This can be directly translated to: Describe one thing that you can observe that shows that energy has [been] released by a chemical reaction. With 17 words in the Swedish version, Packing is given by the normalized value (i.e. z-scores) of 3/17 nouns (sak, energi, reaktion) added to the normalized value of $4 / 17$ long words (beskriv, observera, frigjorts, reaktion) divided by two (as there are two linguistic features added together). Normalizations are needed, for example, because there are always nouns present in an item, but usually - although not in this example - not as many long words, and without normalization, the sheer number of nouns could drown any contribution of long words. Normalization thus allows linguistic features of different 'concentrations' to be added together.

In accordance with earlier research, with higher degrees of Packing, Precision, Personification, and Presentation, it is expected to be harder for students to solve items. Using meaning dimensions to analyse TIMSS 2011 science items, Persson et al. (in press) found that physics items often have low levels of Packing and high levels of Precision, while the reverse is the case with biology items. Earth science items were shown to have very low levels of Personification, especially compared with physics items. Higher levels of Presentation were often found in chemistry items. These findings are summarized in Table 2, which shows how language use in each subject differs from the average language use in all TIMSS science items together (deviation). Table 2 also shows how widespread language use is for each meaning dimension between the items within each subject (dispersion).

This study thus aims to fill a gap in earlier research by placing a method for automated quantitative analysis of scientific texts within a theoretical framework, while also making use of a large amount of empirical material to investigate possible correlations between linguistic features and the results of different groups of students.

\section{Theoretical framework}

Students' encounters with the text, their reading and solving of tasks, are viewed through the lens of the didactically based reception-theoretical perspective 
Table 2. Overview of subjects' deviations from TIMSS 2011 average language use regarding meaning dimensions in all Swedish science items and the measurements dispersions

\begin{tabular}{|c|c|c|c|c|c|c|c|c|}
\hline \multirow{3}{*}{$\begin{array}{l}\text { Language use } \\
\text { in subject }\end{array}$} & \multicolumn{8}{|c|}{ Meaning dimensions } \\
\hline & \multicolumn{2}{|c|}{ Packing } & \multicolumn{2}{|c|}{ Precision } & \multicolumn{2}{|c|}{ Personification } & \multicolumn{2}{|c|}{ Presentation } \\
\hline & Deviation & Dispersion & Deviation & Dispersion & Deviation & Dispersion & Deviation & Dispersion \\
\hline Biology & + & $\mathrm{H},(\mathrm{S})$ & - & $\mathrm{L},(\mathrm{S})$ & - & A, $S$ & 0 & A, $S$ \\
\hline Chemistry & 0 & $\mathrm{H}$ & 0 & $\mathrm{H}$ & + & $\mathrm{H}, \mathrm{S}$ & + & $\mathrm{H}, \mathrm{S}$ \\
\hline Earth science & 0 & A & 0 & $\mathrm{H}$ & - & (NA), S & 0 & A, $S$ \\
\hline Physics & - & $\mathrm{L},(\mathrm{S})$ & + & $\mathrm{H}$ & + & $\mathrm{H}, \mathrm{S}$ & 0 & A, $S$ \\
\hline
\end{tabular}

Deviations from average language use in TIMSS: + : above; - : below; 0: close to average.

Dispersions of measurements: H: high; L: low; A: average; (NA): too few valid measurements.

S: skewed distribution (i.e. many low scores); (S): slightly skewed distribution.

(N.B. 'didactic' in the continental European 'educational' sense, not in the Anglo-American 'sententious' way, cf. Hopmann, 2007). The didactically based reception-theoretical perspective is founded on the didactical triangle's cornerstones: who (student), what (intended content), and how (practices in the teaching situation) creates a didactical platform for the use of reception theory, where the encounter between the reader (who) and the text (what) in a specific reading situation (how) is in focus (Liberg, Folkeryd, af Geijerstam, \& Edling, 2002). In reception theory (e.g. McCormick, 1994), readers are not considered passive receivers of content; they are seen as actively creating meaning by using their experiences and prior knowledge. From this perspective, a text is not cognitively demanding in itself (Schleppegrell, 2004); it depends on the relationship between the reader and the text in the situation where the encounter is taking place (e.g. Liberg et al., 2002; Sweet $\&$ Snow, 2003). As shown in the earlier research above, important characteristics of the reader in this relationship concern his/her socio-cultural background, reading experience, knowledge and interest in the subject area, and experience with participation in contexts in which the subject is taught. Aspects of interest regarding the text include the cognitive domains of the content, vocabulary (e.g. everyday versus subject-specific), how dense or packed and precise the information is, how personal relationships are expressed, and how the information is presented or organised on both micro level (clause level) and macro level (genre). Based on the didactical platform, reception theory makes it possible to interpret the meaning-making and the result of the meaning-making that occurs in a student's encounter with the meaning that is offered through the text (cf. Langer, 2011; Liberg, Geijerstam, \& Folkeryd, 2011). The present study is particularly focused on achievement level as a characteristic of students combined with the four meaning dimensions as expressed in the language used in the TIMSS 2011 science items. 


\section{Data}

The empirical data comprises the Swedish TIMSS 2011 8th grade science items, test scores, and students' background data. TIMSS is considered to cover $96 \%$ of the components of Swedish science curricula in use at the time of the test (Skolverket, 2006).

The analysis excludes students who did not answer any science items (i.e. who only responded to mathematical items). Items consisting of several parts using the same leading text were merged to make sure the linguistic features were only counted once. The resulting 197 items were separated into subjects (Table 3) and item types (Table 4).

Table 3. Item separation into subjects

\begin{tabular}{lc}
\hline Subjects & Number of items \\
\hline Biology & 69 \\
Chemistry & 44 \\
Earth science & 35 \\
Physics & 49 \\
Total & 197 \\
\hline
\end{tabular}

Table 4. Item separation into item types

\begin{tabular}{lc}
\hline Item type $^{\mathrm{a}}$ & Number of items \\
\hline Constructed response, CR & 86 \\
Multiple choice, MC & 108 \\
Total & 194 \\
\hline
\end{tabular}

${ }^{a}$ Three merged items with both MC and CR parts are excluded from the analysis.

In this study, student responses coded by the IEA as 'not reached' are not considered existing answers. Responses coded as 'omitted' are considered faulty responses. The use of actual student responses (i.e. not imputing statistically estimated responses calculated from students' actual responses), results in the number of responses to items, ranging from 624 to 803 (Table 5) Students were separated into girls and boys, and their overall performance in science was separated into 1 st and 4 th quartiles (low/high-performing 25\%).

\section{Method}

Responses belonging to different student groups All students, Boys, Girls, First quartile ( $<36 \%$ correct responses) and Fourth quartile ( $>62.96 \%$ correct responses) were identified (Table 5). Per cent right scores were calculated by dividing each group's 
average score on a given item by the item's maximum score, thus enabling comparisons of items with different maximum points.

Values for the four meaning dimensions Packing, Precision, Personification and Presentation were calculated for each item by dividing linguistic features (Table 1) by the number of words in the item (compensating for differences in text length); they were then standardized (enabling the addition of features with different concentrations), added together, and finally divided by the number of features added.

As Shapiro-Wilk tests indicated that the linguistic features used were unlikely to be normally distributed, use of multiple regression analysis or Pearson correlation was not suitable for this kind of data. Instead, the meaning dimensions were individually tested for bivariate correlations with each student group's per cent of correct scores using a two-tailed Spearman's rank correlation test. The data were split into subjects and item formats and analysed again for correlations. The number of items was not large enough to allow for splitting into subjects and item formats at the same time.

Using the original (i.e. non-standardized) values for linguistic features, one linguistic surface feature (number of words), one readability formula (LIX), and four measures of information load that are compatible with Swedish (Nominal Ratio, Simple Nominal Ratio, Nouns per Pronouns, Lexical Density) were also tested for correlations with the same method used for meaning dimensions. The Nouns per Pronouns ratio was calculated using all pronouns, and Lexical Density was calculated as content words (nouns, proper and descriptive names, adjectives, adverbs, participles, non-auxiliary verbs) per word.

\section{Results in light of the theoretical framework}

This section presents and interprets the results from the didactically based receptiontheoretical perspective (Liberg et al., 2002). The results from the correlation analysis are shown in six tables: all subject areas combined, each of the four subjects, and also for constructed response items. A table for multiple choice items is not presented here, as no significant correlations were found. Each table shows the five student

Table 5. Number of students responding

\begin{tabular}{lccccc}
\hline & & & \multicolumn{2}{c}{ Number of responses per item } \\
\cline { 4 - 6 } Student group & Number of students & Proportion of girls (\%) & Min. & Max. & Average \\
\hline All & 5,516 & 48.1 & 624 & 803 & 783 \\
Boys & $2,857^{\mathrm{a}}$ & - & 301 & 426 & 406 \\
Girls & $2,654^{\mathrm{a}}$ & - & 316 & 401 & 376 \\
1st quartile & 1,378 & 47.0 & 97 & 298 & 194 \\
4th quartile & 1,384 & 45.9 & 117 & 290 & 197 \\
\hline
\end{tabular}

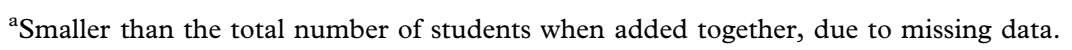


groups and the four meaning dimensions; other measures are included only if statistically significant correlations are found (full versions of all tables without the excluded results can be found at the end of the article). When interpreting the strength of the relationships between the variables, a correlation coefficient size of 0.1 can generally be regarded as a small effect accounting for $1 \%$ of the variance, 0.3 as a medium effect accounting for $9 \%$ of the variance, and 0.5 as a large effect accounting for $25 \%$ of the variance (Field, 2013). When conducting tests, there is a risk of falsely indicating results as significant. With a level of significance set at 0.05 , 1 result out of 20 can be expected to be significant purely by chance, even with random data. Although some results in this study are also significant at higher levels $(p<0.01$ and $p<0.005)$ and therefore less likely to be caused by such errors, this is a limitation that must be considered when interpreting the results presented in the tables. The number of items decreases when separated into subjects and types, and responses decrease due to the use of actual student responses and the separation of students into groups, thus making it harder to have enough data to reach significant levels. Still, there are almost 100-300 responses for each item, even for the smallest partitions (Table 5).

The didactically based reception-theoretical perspective (Liberg et al., 2002) makes it possible to interpret results for the complex issue of encounters between students with certain prerequisites and the TIMSS items. Important prerequisites for students include experience with reading, which is closely linked to performance in science (cf. Cromley, 2009), interest in the subject (cf. Adolfsson, 2011), knowledge of the subject, and the ability to read and use characteristic linguistic features of the subject (cf. Kokkinakis \& Frändberg, 2013). Important features of the TIMSS items include how dense or packed the information is, how precise it is, how it is presented, and how it connects with a reader on a personal level.

\subsection{All subject areas in science}

Packing, measured in this study by the use of nouns and long words, does not show any significant correlations for all subject areas combined (Table 6). On the contrary, increased levels of Precision, that is, the use of different types of modifiers, have significant positive correlations with results for both girls and high performers. As both groups are likely to be better readers (Skolverket, 2012a, 2012b, 2012c, 2013), increased Precision is interpreted as beneficial to skilled readers. Less skilled readers are likely to be found among low performers, who are interpreted as being impeded by texts with an increased number of words, as shown in Table 6.

Higher levels of both Personification and Presentation are interpreted (in accordance with earlier research) as negatively influencing performance for many of the groups. Girls are an exception to this when it comes to Presentation, which is interpreted to be the result of the fact that girls are generally better readers and thus better able to handle more complex text structures. Furthermore, increased levels of Personification have a negative correlation for all groups except high performers. In this study, Personification is measured by the use of proper names and personal pronouns, which provide items with an everyday context and/or establish personal relationships with 


\section{Tomas Persson}

Table 6. All subject areas combined

\begin{tabular}{|c|c|c|c|c|c|}
\hline $\begin{array}{l}\text { Spearman's rank } \\
\text { correlation }\end{array}$ & & Correlati & ion coefficient (signifi & icance level) & \\
\hline All items, $N=197$ & Packing & Precision & Personification & Presentation & Number of words \\
\hline $\begin{array}{l}\text { All students, } \\
\qquad N=5,516\end{array}$ & $0.041(0.564)$ & $0.135(0.059)$ & $-0.188^{\star \star}(0.008)$ & $-0.162^{\star}(0.023)$ & $-0.081(0.257)$ \\
\hline Girls, $N=2,654$ & $0.027(0.707)$ & $0.146^{\star}(0.041)$ & $-0.157^{\star}(0.027)$ & $-0.137(0.054)$ & $-0.061(0.397)$ \\
\hline Boys, $N=2,857$ & $0.055(0.442)$ & $0.127(0.076)$ & $-0.201^{\star \star \star}(0.005)$ & $-0.180^{\star}(0.011)$ & $-0.091(0.204)$ \\
\hline $\begin{array}{l}\text { 1st quartile, } \\
\qquad N=1,378\end{array}$ & $0.119(0.096)$ & $0.068(0.345)$ & $-0.287^{\star \star \star}(0.000)$ & $-0.144^{\star}(0.043)$ & $-0.165^{\star}(0.021)$ \\
\hline $\begin{array}{l}\text { 4th quartile, } \\
\qquad N=1,384\end{array}$ & $0.036(0.611)$ & $0.153^{\star}(0.031)$ & $-0.108(0.130)$ & $-0.171^{\star}(0.016)$ & $-0.066(0.357)$ \\
\hline
\end{tabular}

Bivariate correlations between students' per cent right and meaning dimensions and number of words.

${ }^{\star}$ Correlation is significant at the 0.05 level (2-tailed), ${ }^{\star}$ at the 0.01 level (2-tailed), ${ }^{\star \star}$ at the 0.005 level (2-tailed), all boldface.

readers. Placing scientific tasks in everyday contexts, as indicated by the use of proper names and pronouns denoting fictitious students, is therefore interpreted as annoying for many students, or as obscuring the scientific problem (cf. Schoultz, 2000; Serder \& Jakobsson, 2014/2015). To a minor extent, this might be influenced by pronouns in phrases such as 'Explain your answer' in constructed response items. However, the only significant correlation found regarding Personification in constructed response items is for low performers (Table 7). A possible interpretation of this is that low performers are more negatively influenced by the request to explain and justify their chosen answer than other groups. As significant correlations are not shown by Nouns per Pronouns, this indicates that, rather than linking all kinds of pronouns to who/what is being referenced (cf. Graesser et al., 2011), linking personal pronouns is what students find especially difficult.

Table 7. Constructed response items

\begin{tabular}{|c|c|c|c|c|}
\hline \multirow{2}{*}{$\begin{array}{l}\text { Spearman's rank correlation } \\
\text { Constructed response items, } N=86\end{array}$} & \multicolumn{4}{|c|}{ Correlation coefficient (significance level) } \\
\hline & Packing & Precision & Personification & Presentation \\
\hline All students, $N=5,516$ & $-0.003(0.977)$ & $0.185(0.089)$ & $-0.137(0.209)$ & $-0.171(0.116)$ \\
\hline Girls, $N=2,654$ & $0.001(0.991)$ & $0.223^{\star}(0.039)$ & $-0.139(0.202)$ & $-0.151(0.164)$ \\
\hline Boys, $N=2,857$ & $0.005(0.965)$ & $0.168(0.123)$ & $-0.126(0.247)$ & $-0.198(0.068)$ \\
\hline 1st quartile, $N=1,378$ & $-0.029(0.789)$ & $0.246^{\star}(0.022)$ & $-0.216^{\star}(0.046)$ & $-0.089(0.418)$ \\
\hline 4 th quartile, $N=1,384$ & $0.052(0.635)$ & $0.101(0.352)$ & $-0.051(0.642)$ & $-0.237^{\star}(0.028)$ \\
\hline
\end{tabular}

Bivariate correlations between students' per cent right and meaning dimensions.

*Correlation is significant at the 0.05 level (2-tailed), all boldface. 
Table 8. Biology items

\begin{tabular}{|c|c|c|c|c|}
\hline \multirow{2}{*}{$\begin{array}{l}\text { Spearman's rank correlation } \\
\text { Biology items, } N=69\end{array}$} & \multicolumn{4}{|c|}{ Correlation coefficient (significance level) } \\
\hline & Packing & Precision & Personification & Presentation \\
\hline All students, $N=5,516$ & $-0.127(0.299)$ & $0.199(0.101)$ & $-0.077(0.532)$ & $-0.249 \star(0.039)$ \\
\hline Girls, $N=2,654$ & $-0.161(0.187)$ & $0.269^{\star}(0.025)$ & $-0.029(0.812)$ & $-0.180(0.139)$ \\
\hline Boys, $N=2,857$ & $-0.079(0.518)$ & $0.150(0.220)$ & $-0.109(0.373)$ & $-0.288^{\star}(0.016)$ \\
\hline 1st quartile, $N=1,378$ & $0.009(0.939)$ & $0.149(0.221)$ & $-0.202(0.097)$ & $-0.270^{\star}(0.025)$ \\
\hline 4 th quartile, $N=1,384$ & $-0.059(0.628)$ & $0.154(0.205)$ & $-0.065(0.596)$ & $-0.281^{\star}(0.019)$ \\
\hline
\end{tabular}

Bivariate correlations between students' per cent right and meaning dimensions.

*Correlation is significant at the 0.05 level (2-tailed), all boldface.

\subsection{Biology and chemistry}

There are some similarities between the overall results for all subject areas and the results in biology (Table 8) and chemistry (Table 9). In both subject areas, and in the overall results, there are no significant correlations for Packing, even though, on average, there are high levels of Packing in biology items and average levels in chemistry items (see Table 2). The nouns and long words used in these subject areas are thus interpreted as having neither a negative nor a positive influence on the studied students' scores.

In biology (Table 8), Precision again shows no significant correlation for many of the groups. Girls are the only group in biology with significant correlations in Precision. As with all subject areas combined, Presentation shows significant negative correlations for all groups except girls. One interpretation of these results is that girls are better readers. Girls also favour biology (Adolfsson, 2011) with slightly better

Table 9. Chemistry items

\begin{tabular}{|c|c|c|c|c|c|}
\hline $\begin{array}{l}\text { Spearman's rank } \\
\text { correlation }\end{array}$ & & Correlat & on coefficient (signi & icance level) & \\
\hline $\begin{array}{l}\text { Chemistry items, } \\
N=44\end{array}$ & Packing & Precision & Personification & Presentation & Number of words \\
\hline $\begin{array}{l}\text { All students, } \\
\qquad N=5,516\end{array}$ & $0.156(0.313)$ & $0.353^{\star}(0.019)$ & $-0.264(0.083)$ & $-0.157(0.307)$ & $-0.088(0.569)$ \\
\hline Girls, $N=2,654$ & $0.117(0.448)$ & $0.322^{\star}(0.033)$ & $-0.222(0.148)$ & $-0.158(0.307)$ & $-0.075(0.628)$ \\
\hline Boys, $N=2,857$ & $0.163(0.291)$ & $0.336^{\star}(0.026)$ & $-0.269(0.078)$ & $-0.144(0.350)$ & $-0.112(0.471)$ \\
\hline $\begin{array}{l}\text { 1st quartile, } \\
\qquad N=1,378\end{array}$ & $0.099(0.521)$ & $0.171(0.267)$ & $-0.391^{\star \star}(0.009)$ & $-0.085(0.584)$ & $-0.301^{\star}(0.047)$ \\
\hline $\begin{array}{l}\text { 4th quartile, } \\
\qquad N=1,384\end{array}$ & $0.132(0.394)$ & $0.409^{\star \star}(0.006)$ & $-0.112(0.470)$ & $-0.209(0.174)$ & $0.043(0.782)$ \\
\hline
\end{tabular}

Bivariate correlations between students' per cent right and meaning dimensions and number of words.

${ }^{\star}$ Correlation is significant at the 0.05 level (2-tailed), ${ }^{\star \star}$ at the 0.01 level (2-tailed), all boldface. 
performances in that subject (Skolverket, 2012b), which could also help explain these correlations. Furthermore, on average, there are low levels of Personification in biology (see Table 2), which may contribute to the absence of a significant correlation with students' scores.

Regarding chemistry (Table 9), the effect sizes reach medium levels for all significant correlations. Increased levels of Precision show a positive correlation for all groups except low performers. On the contrary, in accordance with results for all subject areas combined, low performers' results show a negative influence with increased levels of Personification and increased text length. One possible explanation for low performers not being able to benefit from increased Precision and the negative influence from increased Personification and text length, could be that low performers are likely to be less skilled readers. Although chemistry items generally have higher levels of both Personification and Presentation (see Table 2), only one significant (negative) correlation is shown, and it is for low performers regarding Personification.

\subsection{Earth science and physics}

The results for earth science (Table 10) and physics (Table 11) stand in contrast to the overall results for all subject areas, as well as for the results for biology and chemistry. The only meaning dimension that shows a significant correlation in earth science and physics is Packing. In earth science, this correlation is positive, while in physics it is negative.

The positive correlation in earth science is identified for both Packing and LIX for most groups of students. This is probably due to both measures using the variable long words per words. Such significant positive correlation, with medium effect sizes for all student groups in focus in this study were unexpected, since longer words are

Table 10. Earth science items

\begin{tabular}{|c|c|c|c|c|c|}
\hline $\begin{array}{l}\text { Spearman's rank } \\
\text { correlation }\end{array}$ & & Correlat & on coefficient ( $\mathrm{sig}$ & nificance level) & \\
\hline $\begin{array}{l}\text { Earth science items, } \\
N=35\end{array}$ & Packing & Precision & Personification & Presentation & $\begin{array}{c}\text { LIX } \\
\text { (readability index) }\end{array}$ \\
\hline $\begin{array}{l}\text { All students, } \\
\qquad N=5,516\end{array}$ & $0.380^{\star}(0.024)$ & $0.238(0.168)$ & $-0.214(0.217)$ & $-0.140(0.422)$ & $0.381^{\star}(0.024)$ \\
\hline Girls, $N=2,654$ & $0.365^{\star}(0.031)$ & $0.258(0.135)$ & $-0.235(0.174)$ & $-0.102(0.559)$ & $0.384^{\star}(0.023)$ \\
\hline Boys, $N=2,857$ & $0.406^{\star}(0.016)$ & $0.242(0.161)$ & $-0.199(0.251)$ & $-0.170(0.329)$ & $0.387^{\star}(0.022)$ \\
\hline $\begin{array}{l}\text { 1st quartile, } \\
\qquad N=1,378\end{array}$ & $0.419^{\star}(0.012)$ & $0.124(0.477)$ & $-0.226(0.192)$ & $-0.210(0.226)$ & $0.313(0.067)$ \\
\hline $\begin{array}{l}4 \text { th quartile, } \\
\qquad N=1,384\end{array}$ & $0.386^{\star}(0.022)$ & $0.333(0.050)$ & $-0.188(0.280)$ & $-0.023(0.894)$ & $0.431^{\star \star}(0.010)$ \\
\hline
\end{tabular}

Bivariate correlations between students' per cent right and meaning dimensions and a readability measure. ${ }^{\star}$ Correlation is significant at the 0.05 level (2-tailed), ${ }^{\star \star}$ at the 0.01 level (2-tailed), all boldface. 
Table 11. Physics items

\begin{tabular}{|c|c|c|c|c|c|c|}
\hline \multirow{2}{*}{$\begin{array}{l}\text { Spearman's rank correlation } \\
\text { Physics items, } N=49\end{array}$} & \multicolumn{6}{|c|}{ Correlation coefficient (significance level) } \\
\hline & Packing & Precision & Personification & Presentation & Lexical density & Nouns per pronouns \\
\hline All students, $N=5,516$ & $-0.288^{\star}(0.045)$ & $-0.179(0.218)$ & $-0.073(0.620)$ & $-0.072(0.623)$ & $-0.366^{\star \star}(0.010)$ & $-0.247(0.088)$ \\
\hline Girls, $N=2,654$ & $-0.291^{\star}(0.043)$ & $-0.178(0.221)$ & $-0.020(0.893)$ & $-0.081(0.581)$ & $-0.350^{\star}(0.014)$ & $-0.284^{\star}(0.048)$ \\
\hline Boys, $N=2,857$ & $-0.282^{\star}(0.049)$ & $-0.175(0.228)$ & $-0.102(0.487)$ & $-0.071(0.627)$ & $-0.371^{\star \star}(0.009)$ & $-0.222(0.126)$ \\
\hline 1st quartile, $N=1,378$ & $-0.070(0.631)$ & $-0.052(0.722)$ & $-0.246(0.089)$ & $-0.014(0.925)$ & $-0.183(0.207)$ & $-0.160(0.273)$ \\
\hline 4 th quartile, $N=1,384$ & $-0.311^{\star}(0.030)$ & $-0.161(0.269)$ & $0.005(0.972)$ & $-0.088(0.548)$ & $-0.386^{\star \star}(0.006)$ & $-0.248(0.086)$ \\
\hline
\end{tabular}

Bivariate correlations between students' per cent right and meaning dimensions and measures of information load and text complexity.

${ }^{\star}$ Correlation is significant at the 0.05 level (2-tailed), ${ }^{\star}$ at the 0.01 level (2-tailed), all boldface. 
expected to make items harder to solve. Explaining this further requires identification and further analysis of the characteristics of the long words.

On the contrary, in physics, both Packing and Lexical Density show significant negative correlations for all groups except low performers. Why low performers do not show such correlations must be investigated further. The Nouns per Pronouns ratio shows its only significant correlation here, indicating that nouns - the linguistic feature shared with Packing - are of special importance here. As Precision and Personification do not show significant correlations, any linguistic features shared with Lexical Density are unlikely to cause high levels of significance for Lexical Density, that is, adjectives, adverbs, participles, and descriptive and proper names. If this is not caused by small contributions from different parts of speech that, in combination, reach significant levels, this implicates nouns and/or non-auxiliary verbs as negatively influencing student performances. This may indicate that verbs in physics function in a way that is not captured by the meaning dimensions, as meaning dimensions consider of nouns and verbs as complementary and therefore only measure nouns.

\section{Discussion}

A previous study (Persson et al., in press) showed that the use of linguistic features expressing the four meaning dimensions varies among the different scientific subjects (biology, chemistry, earth science, and physics) in TIMSS 2011. The present study problematizes whether or not these differences are significant for different groups of students in their encounters with the TIMSS items, by interpreting correlations between meaning dimensions and students' test results using the didactically based reception theory (Liberg et al., 2002). To conclude, the results of the present study generally indicate that each subject area has one prominent meaning dimension demonstrating significant correlations for several of the studied student groups. In this respect, biology is characterized by the Presentation of information, where the significant negative correlations found are interpreted as indicating an obstacle to all groups studied except girls. In chemistry items, the Precision of information shows significant positive correlations of medium effect size, which is interpreted as supporting all groups studied except low performers. Earth science shows significant positive correlations of medium effect size regarding the Packing of information, which is interpreted as supporting all groups studied. Finally, physics is characterized by significant positive correlations of small to medium effect sizes, where a low level of Packing of information is interpreted as an obstacle for all groups studied except low performers.

Regarding the different groups of students, differences are found between boys and girls (cf. Skolverket, 2012b) in all subject areas combined, and in biology, where girls are interpreted as being aided by Precision and unaffected by negative influences from Presentation. Increased levels of Precision in constructed response items are also interpreted as an aid for girls (Table 7). Although Swedish students have historically shown large correlations between results, gender, and item type (cf. Eriksson, 2005; Hastedt \& Sibberns, 2005), this is the only significant correlation found in this study 
regarding gender and item type. As previously stated, these differences might be explained by the fact that girls are better readers and have a more positive attitude towards biology.

It is noteworthy that the meaning dimensions with a significant influence on the results of low performers often have no influence on high performers, while other meaning dimensions influencing the results of high performers do not influence low performers. The only exceptions are Presentation in all subject areas combined and in biology, and Packing in earth science. This indicates that the two groups behave differently and therefore might benefit from differentiated teaching focusing on different characteristics of the scientific language.

Packing and Precision are both part of ideational meaning, but their differences in the results of this study indicate that they are truly different dimensions of ideational meaning. This demonstrates the complexity of language use and the need to separate linguistic features with different functions in the text from each other. Packing also shows contradictory results, with medium-sized effects for both physics and earth science, but negative correlations with students' results in physics and positive correlations in earth science, the latter of which is probably influenced by the use of some fairly long words. The interpretation of the results also shows that high levels of Precision aid skilled readers rather than being an obstacle to less skilled readers. This indicates a specific need for less skilled readers that teachers must address. Higher levels of Personification reduce the likelihood of items being answered correctly (Table 6) for all groups except high performers. This might be interpreted as high performers being able to 'accept' the placement of scientific problems in an everyday context, without being distracted or annoyed by the use of personal pronouns or names of fictitious places or students, as indicated by previous research (cf. Serder \& Jakobsson, 2014/2015). However, the use of names and personal pronouns is uncommon in TIMSS items, which might explain the lack of significant results when separating items into subjects; there are simply too few items containing such features. Why proper names and personal pronouns have these negative consequences and whether they also have them in other reading situations in school science is an area for further investigation, as this has serious implications for the formulation of science texts. Presentation, the use of subordinated clauses and passives, negatively influences student performances in all subject areas combined and in biology. As discussed above, girls' positive attitudes towards biology and higher reading proficiency can explain why girls do not show the same negative correlations as other groups.

The established measures showed surprisingly few statistically significant correlations. The two Nominal Ratios did not show any significant correlations; Nouns per Pronouns only showed one. Lexical Density showed correlations in physics, with larger effect sizes and higher levels of significance than Packing, thus apparently capturing the information load in physics items as well. Increased item length was not expected to only cause difficulties for low performers, and furthermore, when broken down into subject, only in chemistry. Perhaps most TIMSS items are too short for textlength-related difficulties to be manifested for the other groups and in the other subjects. This method comparison shows that the use of meaning dimensions can be 
regarded as an enriching and complementary method to traditional automated text analysis methods, at least for the analysis of shorter science items similar to those used in TIMSS.

When looking at correlation coefficients, it is possible to jump to conclusions; for example, Table 8 shows that high performers are more negatively influenced by Presentation in biology than low performers. Reception theory is helpful here, pointing to other aspects that might be important, as in the case of low performers. They may be more influenced by other aspects, such as a lack of prior knowledge in the subject area or lack of interest in biology, which takes precedence over any presence of passives and subordinations in items. In the same way, the lack of significant results for Presentation in chemistry (Table 9) does not imply that it is irrelevant for students. Rather, one interpretation could be that chemistry has other issues that overshadow additional complications caused by complex presentations of content. As the statistical saying goes: absence of proof is not proof of absence.

Therefore, significant results should be interpreted as indications of languagerelated aspects influencing students' results, which teachers should be aware of in order to be able to take appropriate actions. A lack of significant results, or significant results with small effect sizes, does not mean that a specific linguistic feature is not an issue for students taking a test or reading a text. It just means that there are other, more significant pitfalls for students.

\section{Conclusion}

This study thus begins to fill a gap found in previous research, while also contributing to the concept of disciplinary literacy in science (cf. Shanahan \& Shanahan, 2008, 2012). Many aspects influence student test scores. A linguistic analysis cannot provide explanations as to why students answer questions the way they do, but it can contribute to the discussion of students' abilities to solve items, such as the ones found on TIMSS featured in this study. Focusing on only one of many other reading situations in school, this study shows the possibility of using meaning dimensions to capture some of the linguistic difficulties students experience when answering science questions.

The diversity of the results for the various subjects indicates not only differences in language use among the scientific subjects but also the influence of language use on different groups of students. By acknowledging the importance of the linguistic features of different types of texts, teachers can take appropriate actions to facilitate students' understanding of how scientific texts are written, both in general and in specific subjects, and thereby presumably also improve student performances. The people responsible for choosing and creating texts intended for use in schools can also be helped by an increased understanding of the possibilities and limitations of using different kinds of readability measures. However, further investigations must be carried out not only on similar tests but also in other reading situations (e.g. textbooks, instructions, teachers' notes) to deepen the understanding of this study's findings. 
This study has shown the strength of using a sociosemiotic perspective to design readability formulas, as the meaning dimensions manage to identify significant correlations between the differences in language use in various subjects and results for different student groups, while many established measures were unable to do so.

\section{References}

Adolfsson, L. (2011). Attityder till naturvetenskap: Förändringar av flickors och pojkars attityder till biologi, fysik och kemi 1995 till 2007 [Attitudes towards science: changes of girls' and boys' attitudes towards biology, physics and chemistry 1995 to 2007]. Studies in science and technology education, 43. Umeå: Institutionen för naturvetenskapens och matematikens didaktik, Umeå universitet.

Bailin, A., \& Grafstein, A. (2001). The linguistic assumptions underlying readability formulae: A critique. Language E Communication, 21(3), 285-301. doi: http://dx.doi.org/10.1016/S0271-5309(01)00005-2

Björnsson, C. H. (1968). Läsbarhet. Solna: Liber.

Cromley, J. G. (2009). Reading achievement and science proficiency: International comparisons from the programme on international student assessment. Reading Psychology, 30(2), 89-118. doi: http://dx.doi.org/ $10.1080 / 02702710802274903$

DuBay, W. H. (2007). Smart language: Readers, readability, and the grading of text. BookSurge Publishing.

Eggins, S. (1994). An introduction to systemic functional linguistics. London: Continuum.

Einarsson, J. (1978). Talad och skriven svenska. Lund: Ekstrand Sociolingvistiska studier.

Eriksson, N. (2005). Prestationsskillnader mellan flickor och pojkar i NO: en studie av uppgiftsformatets betydelse i TIMSS 2003. Umeå: Institutionen för beteendevetenskapliga mätningar, Umeå universitet.

Field, A. (2013). Discovering statistics using IBM SPSS statistics: And sex and drugs and rock ' $n$ ' roll. London: Sage.

Foy, P., Arora, A., \& Stanco, G. M. (Eds.). (2013). Timss 2011 user guide for the international database. Released items. Science eighth grade. TIMSS \& PIRLS International Study Center, Lynch School of Education, Boston: Boston College and International Association for the Evaluation of Educational Achievement (IEA).

Graesser, A. C., McNamara, D. S., \& Kulikowich, J. M. (2011). Coh-metrix: Providing multilevel analyses of text characteristics. Educational Researcher, 40(5), 223-234. doi: http://dx.doi.org/10.3102/ 0013189X11413260

Halliday, M. A. K., \& Martin, J. R. (1993). Writing science: Literacy and discursive power. Pittsburgh, NJ: University of Pittsburgh Press.

Halliday, M. A. K., \& Matthiessen, C. M. I. M. (2004). An introduction to functional grammar (3th ed.). London: Arnold.

Harlow, A., \& Jones, A. (2004). Why students answer TIMSS science test items the way they do. Research in Science Education, 34, 221-238. doi: http://dx.doi.org/10.1023/B:RISE.0000033761.79449.56

Hastedt, D., \& Sibberns, H. (2005). Differences between multiple choice items and constructed response items in the IEA TIMSS surveys. Studies in Educational Evaluation, 31(2), 145-161. doi: http://dx.doi.org/10. 1016/j.stueduc.2005.05.007

Heimann Mühlenbock, K. (2013). I see what you mean: Assessing readability for specific target groups. Data linguistica. No. 24, Institutionen för svenska språket, Gothenburg: University of Gothenburg.

Hogan, T. P., \& Murphy, G. (2007). Comparative review: Recommendations for preparing and scoring constructed-response items: What the experts say. Applied Measurement in Education, 20(4), 427-441. doi: http://dx.doi.org/10.1080/08957340701580736

Hopmann, S. (2007). Restrained teaching: The common core of didaktik. European Educational Research fournal, 6(2), 109-124. doi: http://dx.doi.org/10.2304/eerj.2007.6.2.109

Hyland, K., \& Tse, P. (2007). Is there an "academic vocabulary?” TESOL Quarterly, 41, 235.

Kincaid, J. P., Fishburne, R. P., Rogers, R. L., \& Chissom, B. S. (1975). Derivation of new readability formulas [Automated Readability Index, Fog Count, and Flesch Reading Ease formula] for Navy enlisted personnel (No. RBR-8-75). Millington, TN: Naval Technical Training Command.

Kokkinakis, S. J., \& Frändberg, B. (2013). Högstadieelevers användning av naturvetenskapligt språkbruk i kemiämnet i TIMSS. Utbildning E Demokrati, 22(3), 53-68.

Langer, J. A. (2011). Envisioning knowledge: Building literacy in the academic disciplines. New York, NY: Teachers College Press.

Laursen, H. P. (2006). Den sproglige dimension i naturfagsundervisningen — fokus på tekstbogen (også) i det flersprogede klasserum. MONA, 2, 27-46. Institut for Naturfagenes Didaktik, Københavns Universitet. 


\section{Tomas Persson}

Lemke, J. L. (1990). Talking science: Language, learning, and values. Norwood, NJ: Ablex.

Liberg, C., af Geijerstam, A., \& Folkeryd, J. W. (2011). Scientific literacy and students' movability in science texts. In C. Linder, L. Östman, D. A. Roberts, P. O. Wickman, G. Erickson, \& A. MacKinnon (Eds.), Exploring the landscape of scientific literacy (pp. 74-89). New York, NY: Routledge.

Liberg, C., Folkeryd, J. W., af Geijerstam, Å., \& Edling, A. (2002). Students' encounter with different texts in school. In K. Nauclér (Ed.), Papers from the Third Conference on Reading and Writing (pp. 46-61). Working Papers no 50, Lund: Lund University, Department of Linguistics.

McCormick, K. (1994). The culture of reading and the teaching of English. Manchester: Manchester University Press.

Mullis, I. V., Martin, M. O., Ruddock, G. J., O’Sullivan, C. Y., \& Preuschoff, C. (2009). TIMSS 2011 assessment frameworks. Boston, MA: Boston College.

Oakland, T., \& Lane, H. B. (2004). Language, reading, and readability formulas: Implications for developing and adapting tests. International fournal of Testing, 4(3), 239-252. doi: http://dx.doi.org/10.1207/ s15327574ijt0403_3

OECD (n.d.). Retrieved from http://www.oecd.org/pisa/aboutpisa/

Olsen, R. V., Turmo, A., \& Lie, S. (2001). Learning about students' knowledge and thinking in science through large-scale quantitative studies. European Fournal of Psychology of Education, 16(3), 403-420.

Persson, T., af Geijerstam, Å., \& Liberg, C. (in press). Features and functions of scientific language(s) - The example TIMSS 2011. Nordic Studies in Science Education.

Rodrigues, M. C., Haladyna, T. M., \& Downing, S. M. (2002). A review of multiple-choice item-writing guidelines for classroom assessment. Applied Measurement in Education, 15(3), 309-334. doi: http://dx.doi. org/10.1207/S15324818AME1503_5

Schleppegrell, M. J. (2004). The language of schooling; a functional linguistics perspective. London: Lawrence Erlbaum Associates.

Schoultz, J. (2000). Att samtala om/i naturvetenskap: Kommunikation, kontext och artefakt. Linköping studies in education and psychology. No 67. Linköping: Linköpings Universitet.

Serder, M., \& Jakobsson, A. (2014/2015). "Why bother so incredibly much?”: Student perspectives on PISA science assignments. Cultural Studies of Science Education, 10(3), 833-853. doi: http://dx.doi.org/10.1007/ s1 1422-013-9550-3

Shanahan, T., \& Shanahan, C. (2008). Teaching disciplinary literacy to adolescents: Rethinking content-area literacy. Harvard Educational Review, 78(1), 40-59, 279.

Shanahan, T., \& Shanahan, C. (2012). What is disciplinary literacy and why does it matter? Topics in Language Disorders, 32(1), 7-18. doi: http://dx.doi.org/10.1097/TLD.0b013e318244557a

Skolverket. (2006). Med fokus på matematik och naturvetenskap: en analys av skillnader och likheter mellan internationella jämförande studier och nationella kursplaner. Stockholm: Skolverket.

Skolverket. (2012a). PIRLS 2011 Läsförmågan hos svenska elever $i$ årskurs 4 i ett internationellt perspektiv. No. 381 . Stockholm: Skolverket.

Skolverket. (2012b). TIMSS 2011 Svenska grundskoleelevers kunskaper $i$ matematik och naturvetenskap $i$ ett internationellt perspektiv. No. 380. Stockholm: Skolverket.

Skolverket. (2012c). Högpresterande elever, höga prestationer och undervisningen. No. 379. Stockholm: Skolverket.

Skolverket. (2013). PISA 2012 15-åringars kunskaper i matematik, läsförståelse och naturvetenskap. No. 398. Stockholm: Skolverket.

Skolverket. (2014). TIMSS 2011 Uppgifter i naturvetenskap, årskurs 8. No. 403. Stockholm: Fritzes.

Sweet, A. P., \& Snow, C. E. (2003). Rethinking reading comprehension. New York: Guilford.

Torvatn, A. C. (2004). Tekststrukturens innvirkning på leseforståelsen. En studie av fire lareboktekster for ungdomstrinnet og sju elevers lesing av dem. Høgskolen i Hedmark Rapport nr. 13 Trondheim: Norges teknisk-naturvitenskaplige Universitet.

Veel, R. (1997). Learning how to mean-scientifically speaking: Apprenticeship into scientific discourse in the secondary school. In F. Christie \& J. R. Martin (Eds.), Genre and Institutions: Social processes in the workplace and school (pp. 161-195). London: Cassell.

Wellington, J., \& Osborne, J. (2001). Language and literacy in science education. Buckingham: Open University Press. 
Appendix

Table 6. (full version). All subject areas combined. Bivariate correlations between students' percent right and meaning dimensions, number of words, readability and information load measures. Significant values are boldface.

\begin{tabular}{|c|c|c|c|c|c|c|c|c|c|c|c|}
\hline $\begin{array}{l}\text { All items, } \\
N=197 \\
(N=194 \text { for } \\
\text { Nouns per } \\
\text { Pronouns) }\end{array}$ & $\begin{array}{l}\text { Spearman's } \\
\text { rank } \\
\text { correlation }\end{array}$ & Packing & Precision & Personification & Presentation & $\begin{array}{c}\text { Number of } \\
\text { words }\end{array}$ & $\begin{array}{c}\text { LIX } \\
\text { (readability } \\
\text { Index) }\end{array}$ & $\begin{array}{l}\text { Content } \\
\text { words per } \\
\text { words }\end{array}$ & $\begin{array}{l}\text { Nominal } \\
\text { ratio }\end{array}$ & $\begin{array}{l}\text { Simple } \\
\text { nominal } \\
\text { ratio }\end{array}$ & $\begin{array}{c}\text { Nouns per } \\
\text { pronouns }\end{array}$ \\
\hline \multirow[t]{2}{*}{$\begin{array}{l}\text { All students, } \\
\qquad N=5,516\end{array}$} & $\begin{array}{l}\text { Correlation } \\
\text { coefficient }\end{array}$ & 0.041 & 0.135 & $-0.188^{\star \star}$ & $-0.162^{\star}$ & -0.081 & 0.093 & 0.040 & 0.079 & 0.079 & 0.057 \\
\hline & Sig. (2-tailed) & 0.564 & 0.059 & 0.008 & 0.023 & 0.257 & 0.196 & 0.579 & 0.268 & 0.269 & 0.433 \\
\hline \multirow[t]{2}{*}{$\begin{array}{l}\text { Girls, } \\
\qquad N=2,654\end{array}$} & $\begin{array}{l}\text { Correlation } \\
\text { coefficient }\end{array}$ & 0.027 & $0.146^{\star}$ & $-0.157^{\star}$ & -0.137 & -0.061 & 0.101 & 0.023 & 0.060 & 0.058 & 0.043 \\
\hline & Sig. (2-tailed) & 0.707 & 0.041 & 0.027 & 0.054 & 0.397 & 0.159 & 0.747 & 0.401 & 0.414 & 0.548 \\
\hline \multirow[t]{2}{*}{$\begin{array}{l}\text { Boys, } \\
\qquad N=2,857\end{array}$} & $\begin{array}{l}\text { Correlation } \\
\text { coefficient }\end{array}$ & 0.055 & 0.127 & $-0.201^{\star \star \star}$ & $-0.180^{\star}$ & -0.091 & 0.085 & 0.057 & 0.094 & 0.091 & 0.072 \\
\hline & Sig. (2-tailed) & 0.442 & 0.076 & 0.005 & 0.011 & 0.204 & 0.233 & 0.427 & 0.189 & 0.203 & 0.317 \\
\hline \multirow[t]{2}{*}{$\begin{array}{r}\text { 1st quartile, } \\
\qquad N=1,378\end{array}$} & $\begin{array}{l}\text { Correlation } \\
\text { coefficient }\end{array}$ & 0.119 & 0.068 & $-0.287^{\star \star \star}$ & $-0.144^{\star}$ & $-0.165^{\star}$ & 0.100 & 0.089 & 0.092 & 0.111 & 0.048 \\
\hline & Sig. (2-tailed) & 0.096 & 0.345 & 0.000 & 0.043 & 0.021 & 0.161 & 0.212 & 0.198 & 0.119 & 0.509 \\
\hline \multirow[t]{2}{*}{$\begin{array}{l}\text { 4th quartile } \\
\qquad N=1,384\end{array}$} & $\begin{array}{l}\text { Correlation } \\
\text { coefficient }\end{array}$ & 0.036 & $0.153^{\star}$ & -0.108 & $-0.171^{\star}$ & -0.066 & 0.116 & 0.014 & 0.104 & 0.094 & 0.089 \\
\hline & Sig. (2-tailed) & 0.611 & 0.031 & 0.130 & 0.016 & 0.357 & 0.106 & 0.844 & 0.147 & 0.191 & 0.216 \\
\hline
\end{tabular}


Table 7. (full version). Constructed response items. Bivariate correlations between students' percent right and meaning dimensions, number of words, readability and information load measures. Significant values are boldface.

\begin{tabular}{|c|c|c|c|c|c|c|c|c|c|c|c|}
\hline $\begin{array}{l}\text { Constructed } \\
\text { response items, } \\
N=86\end{array}$ & $\begin{array}{l}\text { Spearman's } \\
\text { rank } \\
\text { correlation }\end{array}$ & Packing & Precision & Personification & Presentation & $\begin{array}{l}\text { Number } \\
\text { of words }\end{array}$ & $\begin{array}{c}\text { LIX } \\
\text { (readability } \\
\text { index) }\end{array}$ & $\begin{array}{c}\text { Content } \\
\text { words per } \\
\text { words }\end{array}$ & $\begin{array}{l}\text { Nominal } \\
\text { ratio }\end{array}$ & $\begin{array}{c}\text { Simple } \\
\text { nominal } \\
\text { ratio }\end{array}$ & $\begin{array}{l}\text { Nouns per } \\
\text { pronouns }\end{array}$ \\
\hline \multirow[t]{2}{*}{$\begin{array}{l}\text { All students, } \\
\qquad N=5,516\end{array}$} & $\begin{array}{l}\text { Correlation } \\
\text { coefficient }\end{array}$ & -0.003 & 0.185 & -0.137 & -0.171 & -0.043 & 0.111 & 0.067 & 0.103 & 0.086 & 0.046 \\
\hline & Sig. (2-tailed) & 0.977 & 0.089 & 0.209 & 0.116 & 0.693 & 0.310 & 0.539 & 0.346 & 0.429 & 0.678 \\
\hline \multirow[t]{2}{*}{$\begin{array}{l}\text { Girls, } \\
\qquad N=2,654\end{array}$} & $\begin{array}{l}\text { Correlation } \\
\text { coefficient }\end{array}$ & 0.001 & $0.223^{\star}$ & -0.139 & -0.151 & -0.016 & 0.124 & 0.051 & 0.116 & 0.092 & 0.046 \\
\hline & Sig. (2-tailed) & 0.991 & 0.039 & 0.202 & 0.164 & 0.885 & 0.257 & 0.640 & 0.287 & 0.400 & 0.680 \\
\hline \multirow[t]{2}{*}{$\begin{array}{l}\text { Boys, } \\
\qquad N=2,857\end{array}$} & $\begin{array}{l}\text { Correlation } \\
\text { coefficient }\end{array}$ & 0.005 & 0.168 & -0.126 & -0.198 & -0.056 & 0.103 & 0.088 & 0.104 & 0.090 & 0.045 \\
\hline & Sig. (2-tailed) & 0.965 & 0.123 & 0.247 & 0.068 & 0.610 & 0.348 & 0.420 & 0.342 & 0.409 & 0.688 \\
\hline \multirow[t]{2}{*}{$\begin{array}{r}\text { 1st quartile, } \\
\qquad N=1,378\end{array}$} & $\begin{array}{l}\text { Correlation } \\
\text { coefficient }\end{array}$ & -0.029 & $0.246^{\star}$ & $-0.216^{\star}$ & -0.089 & -0.035 & 0.081 & 0.067 & 0.073 & 0.065 & 0.061 \\
\hline & Sig. (2-tailed) & 0.789 & 0.022 & 0.046 & 0.418 & 0.752 & 0.459 & 0.540 & 0.502 & 0.553 & 0.583 \\
\hline \multirow[t]{2}{*}{$\begin{array}{r}4 \text { th quartile, } \\
\quad N=1,384\end{array}$} & $\begin{array}{l}\text { Correlation } \\
\text { coefficient }\end{array}$ & 0.052 & 0.101 & -0.051 & $-0.237^{\star}$ & -0.051 & 0.151 & 0.048 & 0.167 & 0.128 & 0.082 \\
\hline & Sig. (2-tailed) & 0.635 & 0.352 & 0.642 & 0.028 & 0.639 & 0.164 & 0.658 & 0.124 & 0.240 & 0.460 \\
\hline
\end{tabular}

${ }^{\star}$ Correlation is significant at the 0.05 level (2-tailed). 
Table 8. (full version). Biology items. Bivariate correlations between students' percent right and meaning dimensions, number of words, readability and information load measures. Significant values are boldface.

\begin{tabular}{|c|c|c|c|c|c|c|c|c|c|c|c|}
\hline $\begin{array}{l}\text { Biology items, } \\
N=69 \\
(N=67 \text { for } \\
\text { nouns per } \\
\text { pronouns) }\end{array}$ & $\begin{array}{c}\text { Spearman's } \\
\text { rank } \\
\text { correlation }\end{array}$ & Packing & Precision & Personification & Presentation & $\begin{array}{l}\text { Number } \\
\text { of words }\end{array}$ & $\begin{array}{c}\text { LIX } \\
\text { (readability } \\
\text { index) }\end{array}$ & $\begin{array}{c}\text { Content } \\
\text { words per } \\
\text { words }\end{array}$ & $\begin{array}{l}\text { Nominal } \\
\text { ratio }\end{array}$ & $\begin{array}{l}\text { Simple } \\
\text { nominal } \\
\text { ratio }\end{array}$ & $\begin{array}{c}\text { Nouns per } \\
\text { pronouns }\end{array}$ \\
\hline \multirow[t]{2}{*}{$\begin{array}{l}\text { All students, } \\
\qquad N=5,516\end{array}$} & $\begin{array}{l}\text { Correlation } \\
\text { coefficient }\end{array}$ & -0.127 & 0.199 & -0.077 & $-0.249^{\star}$ & -0.020 & -0.111 & -0.054 & 0.128 & 0.100 & 0.085 \\
\hline & Sig. (2-tailed) & 0.299 & 0.101 & 0.532 & 0.039 & 0.869 & 0.365 & 0.659 & 0.295 & 0.412 & 0.492 \\
\hline \multirow[t]{2}{*}{$\begin{array}{l}\text { Girls, } \\
\qquad N=2,654\end{array}$} & $\begin{array}{l}\text { Correlation } \\
\text { coefficient }\end{array}$ & -0.161 & $0.269^{\star}$ & -0.029 & -0.180 & 0.012 & -0.099 & -0.091 & 0.083 & 0.050 & 0.058 \\
\hline & Sig. (2-tailed) & 0.187 & 0.025 & 0.812 & 0.139 & 0.920 & 0.418 & 0.459 & 0.497 & 0.681 & 0.639 \\
\hline \multirow[t]{2}{*}{$\begin{array}{l}\text { Boys, } \\
\qquad N=2,857\end{array}$} & $\begin{array}{l}\text { Correlation } \\
\text { coefficient }\end{array}$ & -0.079 & 0.150 & -0.109 & $-0.288^{\star}$ & -0.039 & -0.101 & -0.016 & 0.166 & 0.131 & 0.123 \\
\hline & Sig. (2-tailed) & 0.518 & 0.220 & 0.373 & 0.016 & 0.747 & 0.409 & 0.893 & 0.174 & 0.282 & 0.322 \\
\hline \multirow[t]{2}{*}{$\begin{array}{l}\text { 1st quartile, } \\
\qquad N=1,378\end{array}$} & $\begin{array}{l}\text { Correlation } \\
\text { coefficient }\end{array}$ & 0.009 & 0.149 & -0.202 & $-0.270^{\star}$ & -0.132 & -0.036 & 0.052 & 0.196 & 0.173 & 0.149 \\
\hline & Sig. (2-tailed) & 0.939 & 0.221 & 0.097 & 0.025 & 0.281 & 0.767 & 0.670 & 0.107 & 0.155 & 0.230 \\
\hline \multirow[t]{2}{*}{$\begin{array}{r}\text { 4th quartile, } \\
\qquad N=1,384\end{array}$} & $\begin{array}{l}\text { Correlation } \\
\text { coefficient }\end{array}$ & -0.059 & 0.154 & -0.065 & $-0.281^{\star}$ & -0.043 & -0.018 & -0.056 & 0.155 & 0.140 & 0.110 \\
\hline & Sig. (2-tailed) & 0.628 & 0.205 & 0.596 & 0.019 & 0.723 & 0.883 & 0.648 & 0.205 & 0.253 & 0.377 \\
\hline
\end{tabular}


Table 9. (full version). Chemistry items. Bivariate correlations between students' percent right and meaning dimensions, number of words, readability and information load measures. Significant values are boldface.

\begin{tabular}{|c|c|c|c|c|c|c|c|c|c|c|c|}
\hline $\begin{array}{l}\text { Chemistry items, } \\
N=44\end{array}$ & $\begin{array}{l}\text { Spearman's } \\
\text { rank } \\
\text { correlation }\end{array}$ & Packing & Precision & Personification & Presentation & $\begin{array}{l}\text { Number } \\
\text { of words }\end{array}$ & $\begin{array}{l}\text { LIX } \\
\text { (readability } \\
\text { index) }\end{array}$ & $\begin{array}{l}\text { Content } \\
\text { words per } \\
\text { words }\end{array}$ & $\begin{array}{l}\text { Nominal } \\
\text { ratio }\end{array}$ & $\begin{array}{l}\text { Simple } \\
\text { nominal } \\
\text { ratio }\end{array}$ & $\begin{array}{l}\text { Nouns per } \\
\text { pronouns }\end{array}$ \\
\hline \multirow[t]{2}{*}{$\begin{array}{l}\text { All students, } \\
\qquad N=5,516\end{array}$} & $\begin{array}{l}\text { Correlation } \\
\text { coefficient }\end{array}$ & 0.156 & $0.353^{\star}$ & -0.264 & -0.157 & -0.088 & 0.159 & 0.208 & 0.187 & 0.133 & 0.180 \\
\hline & Sig. (2-tailed) & 0.313 & 0.019 & 0.083 & 0.307 & 0.569 & 0.302 & 0.177 & 0.225 & 0.390 & 0.243 \\
\hline \multirow[t]{2}{*}{$\begin{array}{l}\text { Girls, } \\
\qquad N=2,654\end{array}$} & $\begin{array}{l}\text { Correlation } \\
\text { coefficient }\end{array}$ & 0.117 & $0.322^{\star}$ & -0.222 & -0.158 & -0.075 & 0.113 & 0.174 & 0.156 & 0.103 & 0.159 \\
\hline & Sig. (2-tailed) & 0.448 & 0.033 & 0.148 & 0.307 & 0.628 & 0.466 & 0.259 & 0.310 & 0.506 & 0.304 \\
\hline \multirow[t]{2}{*}{$\begin{array}{l}\text { Boys, } \\
\qquad N=2,857\end{array}$} & $\begin{array}{l}\text { Correlation } \\
\text { coefficient }\end{array}$ & 0.163 & $0.336^{\star}$ & -0.269 & -0.144 & -0.112 & 0.171 & 0.211 & 0.175 & 0.118 & 0.163 \\
\hline & Sig. (2-tailed) & 0.291 & 0.026 & 0.078 & 0.350 & 0.471 & 0.266 & 0.169 & 0.256 & 0.446 & 0.289 \\
\hline \multirow[t]{2}{*}{$\begin{array}{l}\text { 1st quartile, } \\
\qquad N=1,378\end{array}$} & $\begin{array}{l}\text { Correlation } \\
\text { coefficient }\end{array}$ & 0.099 & 0.171 & $-0.391^{\star \star}$ & -0.085 & $-0.301^{\star}$ & 0.051 & 0.130 & 0.079 & 0.077 & 0.000 \\
\hline & Sig. (2-tailed) & 0.521 & 0.267 & 0.009 & 0.584 & 0.047 & 0.742 & 0.400 & 0.611 & 0.621 & 0.998 \\
\hline \multirow[t]{2}{*}{$\begin{array}{l}4 \text { th quartile, } \\
\qquad N=1,384\end{array}$} & $\begin{array}{l}\text { Correlation } \\
\text { coefficient }\end{array}$ & 0.132 & $0.409^{\star \star}$ & -0.112 & -0.209 & 0.043 & 0.191 & 0.182 & 0.208 & 0.126 & 0.257 \\
\hline & Sig. (2-tailed) & 0.394 & 0.006 & 0.470 & 0.174 & 0.782 & 0.213 & 0.236 & 0.176 & 0.414 & 0.092 \\
\hline
\end{tabular}

${ }^{\star}$ Correlation is significant at the 0.05 level (2-tailed). ${ }^{\star \star}$ Correlation is significant at the 0.01 level (2-tailed). 
Table 10. (full version). Earth science items. Bivariate correlations between students' percent right and meaning dimensions, number of words, readability and information load measures. Significant values are boldface.

\begin{tabular}{|c|c|c|c|c|c|c|c|c|c|c|c|}
\hline $\begin{array}{l}\text { Earth Science items, } \\
N=35 \\
\text { ( } N=34 \text { for nouns } \\
\text { per pronouns) }\end{array}$ & $\begin{array}{l}\text { Spearman's } \\
\text { rank } \\
\text { correlation }\end{array}$ & Packing & Precision & Personification & Presentation & $\begin{array}{l}\text { Number } \\
\text { of words }\end{array}$ & $\begin{array}{c}\text { LIX } \\
\text { (readability } \\
\text { index) }\end{array}$ & $\begin{array}{l}\text { Content } \\
\text { words per } \\
\text { words }\end{array}$ & $\begin{array}{l}\text { Nominal } \\
\text { ratio }\end{array}$ & $\begin{array}{l}\text { Simple } \\
\text { nominal } \\
\text { ratio }\end{array}$ & $\begin{array}{l}\text { Nouns per } \\
\text { pronouns }\end{array}$ \\
\hline \multirow[t]{2}{*}{$\begin{array}{l}\text { All students, } \\
\qquad N=5,516\end{array}$} & $\begin{array}{l}\text { Correlation } \\
\text { coefficient }\end{array}$ & $0.380^{\star}$ & 0.238 & -0.214 & -0.140 & -0.057 & $0.381^{\star}$ & 0.277 & 0.115 & 0.210 & 0.130 \\
\hline & Sig. (2-tailed) & 0.024 & 0.168 & 0.217 & 0.422 & 0.744 & 0.024 & 0.108 & 0.509 & 0.225 & 0.464 \\
\hline \multirow[t]{2}{*}{$\begin{array}{l}\text { Girls, } \\
\qquad N=2,654\end{array}$} & $\begin{array}{l}\text { Correlation } \\
\text { coefficient }\end{array}$ & $0.365^{\star}$ & 0.258 & -0.235 & -0.102 & -0.001 & $0.384^{\star}$ & 0.255 & 0.121 & 0.206 & 0.138 \\
\hline & Sig. (2-tailed) & 0.031 & 0.135 & 0.174 & 0.559 & 0.996 & 0.023 & 0.140 & 0.488 & 0.235 & 0.436 \\
\hline \multirow[t]{2}{*}{$\begin{array}{l}\text { Boys, } \\
\qquad N=2,857\end{array}$} & $\begin{array}{l}\text { Correlation } \\
\text { coefficient }\end{array}$ & $0.406^{\star}$ & 0.242 & -0.199 & -0.170 & -0.067 & $0.387^{\star}$ & 0.289 & 0.143 & 0.240 & 0.165 \\
\hline & Sig. (2-tailed) & 0.016 & 0.161 & 0.251 & 0.329 & 0.701 & 0.022 & 0.092 & 0.412 & 0.166 & 0.352 \\
\hline \multirow[t]{2}{*}{$\begin{array}{l}\text { 1st quartile, } \\
\qquad N=1,378\end{array}$} & $\begin{array}{l}\text { Correlation } \\
\text { coefficient }\end{array}$ & $0.419^{\star}$ & 0.124 & -0.226 & -0.210 & -0.105 & 0.313 & 0.289 & 0.122 & 0.241 & 0.098 \\
\hline & Sig. (2-tailed) & 0.012 & 0.477 & 0.192 & 0.226 & 0.547 & 0.067 & 0.092 & 0.483 & 0.163 & 0.582 \\
\hline \multirow[t]{2}{*}{$\begin{array}{r}4 \text { th quartile, } \\
\quad N=1,384\end{array}$} & $\begin{array}{l}\text { Correlation } \\
\text { coefficient }\end{array}$ & $0.386^{\star}$ & 0.333 & -0.188 & -0.023 & -0.037 & $0.431^{\star \star}$ & 0.334 & 0.172 & 0.204 & 0.221 \\
\hline & Sig. (2-tailed) & 0.022 & 0.050 & 0.280 & 0.894 & 0.834 & 0.010 & 0.050 & 0.322 & 0.239 & 0.209 \\
\hline
\end{tabular}


Table 11. (full version). Physics items. Bivariate correlations between students' percent right and meaning dimensions, number of words, readability and information load measures. Significant values are boldface.

\begin{tabular}{|c|c|c|c|c|c|c|c|c|c|c|c|}
\hline $\begin{array}{l}\text { Physics items, } \\
N=49\end{array}$ & $\begin{array}{l}\text { Spearman's } \\
\text { rank } \\
\text { correlation }\end{array}$ & Packing & Precision & Personification & Presentation & $\begin{array}{l}\text { Number } \\
\text { of words }\end{array}$ & $\begin{array}{l}\text { LIX } \\
\text { (readability } \\
\text { index) }\end{array}$ & $\begin{array}{c}\text { Content } \\
\text { words per } \\
\text { words }\end{array}$ & $\begin{array}{l}\text { Nominal } \\
\text { ratio }\end{array}$ & $\begin{array}{l}\text { Simple } \\
\text { nominal } \\
\text { ratio }\end{array}$ & $\begin{array}{c}\text { Nouns per } \\
\text { pronouns }\end{array}$ \\
\hline \multirow[t]{2}{*}{$\begin{array}{l}\text { All students, } \\
N=5,516\end{array}$} & $\begin{array}{l}\text { Correlation } \\
\text { coefficient }\end{array}$ & $-0.288^{\star}$ & -0.179 & -0.073 & -0.072 & -0.103 & -0.002 & $-0.366^{\star \star}$ & -0.252 & -0.254 & -0.247 \\
\hline & Sig. (2-tailed) & 0.045 & 0.218 & 0.620 & 0.623 & 0.483 & 0.987 & 0.010 & 0.080 & 0.079 & 0.088 \\
\hline \multirow[t]{2}{*}{$\begin{array}{l}\text { Girls, } \\
\qquad N=2,654\end{array}$} & $\begin{array}{l}\text { Correlation } \\
\text { coefficient }\end{array}$ & $-0.291^{\star}$ & -0.178 & -0.020 & -0.081 & -0.078 & 0.020 & $-0.350^{\star}$ & -0.255 & -0.261 & $-0.284^{\star}$ \\
\hline & Sig. (2-tailed) & 0.043 & 0.221 & 0.893 & 0.581 & 0.596 & 0.894 & 0.014 & 0.077 & 0.070 & 0.048 \\
\hline \multirow[t]{2}{*}{$\begin{array}{l}\text { Boys, } \\
\qquad N=2,857\end{array}$} & $\begin{array}{l}\text { Correlation } \\
\text { coefficient }\end{array}$ & $-0.282^{\star}$ & -0.175 & -0.102 & -0.071 & -0.135 & -0.035 & $-0.371^{\star \star}$ & -0.241 & -0.245 & -0.222 \\
\hline & Sig. (2-tailed) & 0.049 & 0.228 & 0.487 & 0.627 & 0.356 & 0.812 & 0.009 & 0.095 & 0.090 & 0.126 \\
\hline \multirow[t]{2}{*}{$\begin{array}{l}\text { 1st quartile, } \\
\qquad N=1,378\end{array}$} & $\begin{array}{l}\text { Correlation } \\
\text { coefficient }\end{array}$ & -0.070 & -0.052 & -0.246 & -0.014 & -0.052 & 0.183 & -0.183 & -0.207 & -0.154 & -0.160 \\
\hline & Sig. (2-tailed) & 0.631 & 0.722 & 0.089 & 0.925 & 0.720 & 0.207 & 0.207 & 0.153 & 0.291 & 0.273 \\
\hline \multirow[t]{2}{*}{$\begin{array}{r}4 \text { th quartile, } \\
\qquad N=1,384\end{array}$} & $\begin{array}{l}\text { Correlation } \\
\text { coefficient }\end{array}$ & $-0.311^{\star}$ & -0.161 & 0.005 & -0.088 & -0.194 & -0.062 & $-0.386^{\star \star}$ & -0.214 & -0.203 & -0.248 \\
\hline & Sig. (2-tailed) & 0.030 & 0.269 & 0.972 & 0.548 & 0.182 & 0.674 & 0.006 & 0.141 & 0.163 & 0.086 \\
\hline
\end{tabular}

${ }^{\star}$ Correlation is significant at the 0.05 level (2-tailed). ${ }^{\star \star}$ Correlation is significant at the 0.01 level (2-tailed). 
Table 12. (full version). Multiple choice items. Bivariate correlations between students' percent right and meaning dimensions, number of words, readability and information load measures. Significant values are boldface.

\begin{tabular}{|c|c|c|c|c|c|c|c|c|c|c|c|}
\hline $\begin{array}{l}\text { Multiple choice } \\
\text { items, } \\
N=108\end{array}$ & $\begin{array}{l}\text { Spearman's } \\
\text { rank } \\
\text { correlation }\end{array}$ & Packing & Precision & Personification & Presentation & $\begin{array}{l}\text { Number } \\
\text { of words }\end{array}$ & $\begin{array}{l}\text { LIX } \\
\text { (readability } \\
\text { index) }\end{array}$ & $\begin{array}{l}\text { Content } \\
\text { words per } \\
\text { words }\end{array}$ & $\begin{array}{l}\text { Nominal } \\
\text { ratio }\end{array}$ & $\begin{array}{l}\text { Simple } \\
\text { nominal } \\
\text { ratio }\end{array}$ & $\begin{array}{l}\text { Nouns per } \\
\text { pronouns }\end{array}$ \\
\hline \multirow[t]{2}{*}{$\begin{array}{l}\text { All students, } \\
\qquad N=5,516\end{array}$} & $\begin{array}{l}\text { Correlation } \\
\text { coefficient }\end{array}$ & -0.088 & 0.050 & 0.113 & -0.028 & -0.042 & -0.002 & -0.083 & -0.038 & -0.070 & 0.045 \\
\hline & Sig. (2-tailed) & 0.364 & 0.610 & 0.243 & 0.771 & 0.666 & 0.986 & 0.394 & 0.697 & 0.472 & 0.642 \\
\hline \multirow[t]{2}{*}{$\begin{array}{l}\text { Girls, } \\
\qquad N=2,654\end{array}$} & $\begin{array}{l}\text { Correlation } \\
\text { coefficient }\end{array}$ & -0.080 & 0.040 & 0.125 & -0.019 & -0.042 & 0.019 & -0.079 & -0.061 & -0.086 & 0.025 \\
\hline & Sig. (2-tailed) & 0.412 & 0.678 & 0.197 & 0.847 & 0.670 & 0.841 & 0.414 & 0.532 & 0.378 & 0.794 \\
\hline \multirow[t]{2}{*}{$\begin{array}{l}\text { Boys, } \\
\qquad N=2,857\end{array}$} & $\begin{array}{l}\text { Correlation } \\
\text { coefficient }\end{array}$ & -0.097 & 0.056 & 0.117 & -0.037 & -0.036 & -0.027 & -0.079 & -0.023 & -0.068 & 0.064 \\
\hline & Sig. (2-tailed) & 0.316 & 0.568 & 0.228 & 0.707 & 0.715 & 0.783 & 0.418 & 0.817 & 0.488 & 0.509 \\
\hline \multirow[t]{2}{*}{$\begin{array}{l}\text { 1st quartile, } \\
\qquad N=1,378\end{array}$} & $\begin{array}{l}\text { Correlation } \\
\text { coefficient }\end{array}$ & 0.000 & -0.130 & 0.075 & -0.018 & -0.181 & -0.014 & -0.028 & -0.022 & -0.051 & 0.015 \\
\hline & Sig. (2-tailed) & 1.000 & 0.180 & 0.438 & 0.852 & 0.061 & 0.884 & 0.772 & 0.825 & 0.598 & 0.876 \\
\hline \multirow[t]{2}{*}{$\begin{array}{l}\text { 4th quartile, } \\
\qquad N=1,384\end{array}$} & $\begin{array}{l}\text { Correlation } \\
\text { coefficient }\end{array}$ & -0.086 & 0.159 & 0.103 & -0.024 & -0.023 & 0.032 & -0.069 & -0.008 & -0.032 & 0.078 \\
\hline & Sig. (2-tailed) & 0.375 & 0.100 & 0.287 & 0.804 & 0.815 & 0.745 & 0.479 & 0.935 & 0.739 & 0.422 \\
\hline
\end{tabular}

